\title{
EFFECT OF FORMALDEHYDE TREATMENT ON BACTERIA- INFECTED HATCHING EGGS OF GALLUS GALLUS DOMESTICUS LINNAEUS, 1758
}

\author{
I-L. B. Amoah, P. Asiedu, C. T. Arthur And I. F. Aboagye* \\ (I-L. B. A. \& I. F. A.: Department of Animal Biology and Conservation Science, \\ University of Ghana, Legon, Accra, Ghana; P. A. \& C. T. A.: Council for Scientific and \\ Industrial Research (CSIR) - Animal Research Institute, Accra, Ghana). \\ *Corresponding author's email: iaboagye@ug.edu.gh
}

\begin{abstract}
The effectiveness of formaldehyde egg disinfection is well documented in literature despite its reported toxicity. This study focused on the need for an optimum formaldehyde concentration (FC) that significantly reduces microbial load with minimal damaging effect on egg viability and hatchability. Using a true experimental design, bacterial load on formaldehyde-treated (FT) and control groups of eggs and hatchability were compared. Gram-staining and biochemical tests identified five bacterial species: Escherichia coli, Enterobacter sp., Bacillus cereus, Staphylococcus aureus and Micrococcus sp. with the two coliform bacteria, E. coli and Enterobacter sp., dominating. Comparison of median differences of bacterial load on eggs before and after formaldehyde treatment by Wilcoxon Signed-Rank Test showed marginal significance in bacterial load reduction $(Z=-2.016, P=0.044)$. This difference was observed for bacterial load between the control group (CG) and the FT group with FC $30 / 20 \mathrm{ml} / \mathrm{g}(U=$ $3.0, P=0.047)$. The hatchability of the CG differed significantly from four FT groups of eggs with FC $30 / 20 \mathrm{ml} / \mathrm{g}$ showing the highest level of significance $\left[\chi^{2}(1)=14.71 ; P=0.0001\right]$. A FC of $30 / 20 \mathrm{ml} / \mathrm{g}$ produced the best domestic fowl egg disinfection compared to other FCs and hatchability decreased with increasing formalin volume.
\end{abstract}

Keywords: Formaldehyde treatment, bacteria-infected eggs, Gallus domesticus

\section{Introduction}

Microbial contamination of hatching eggs is a major issue in poultry production, as it can kill developing embryos, reduce hatchability and cause poor chick performance (Scott \& Swetnam, 1993; Willinghan et al., 1996; Fasenko et al., 2009). At the right environmental conditions of soil, dust, dirty nesting materials (Abdul et al., 2012) and optimal conditions of temperature, nutrients and humidity (Graham et al., 2018), hatching eggs and chicks are at high risk of exposure to many species of microorganisms including bacteria and fungi (Oviasogie et al., 2016) and may ultimately lead to economic losses (Bailey et al., 1998; Kim et al., 2007). Some important groups of pathogens identified to be present in large amounts in hatch cabinets include Escherichia coli, Pseudomonas, Staphylococcus, Salmonella spp. and Aspergillus (Berrang et al., 1995), highlighting the importance of effective control of microbial contamination of eggs.

Fumigation of hatching eggs with formaldehyde has been described as one 
of the most effective methods of reducing bacterial load on eggs (Whistler \& Sheldon, 1989; Kaudla, 1999; Yildirim et al., 2003; Cadirci, 2009), as it kills most viruses, bacteria (including their spores) and fungi (Salthammer et al., 2010; Swenberg et al., 2013). Although, formaldehyde is toxic and is reported to be carcinogenic to humans (USDHHS, 2010) and can be seriously damaging to embryo (Jasanoff, 1987; Hayretdag \& Kolankaya, 2008), it is extensively used for microbial control within hatch cabinets (Cadirci, 2009; Kim \& Kim, 2010) on account of its effectiveness. It is, therefore, imperative to find an optimum formaldehyde concentration that significantly reduces microbial load and at the same time have less damaging effects on egg viability and hatchability. This study assessed the effect of varied formaldehyde concentrations on bacterial load on Gallus gallus domesticus egg shell and hatchability.

\section{Experimental}

Study area and sample collection

The study was carried out at the Council for Scientific and Industrial Research (CSIR)Animal Research Institute located in the Adenta Municipal District $\left(5^{\circ} 42^{\prime} 25^{\prime \prime} \mathrm{N}\right.$ $0^{\circ} 10^{\prime} 15^{\prime \prime} \mathrm{W}$ ) in the Greater Accra Region of Ghana. Eggs $(\mathrm{N}=210)$, collected from the University of Ghana Farms, were transported to the hatchery unit, CSIR-Animal Research Institute and randomly allocated to 7 groups with 30 eggs per group.

\section{Sample preparation}

From each crate, six eggs were pulled to form a specimen and treated with different concentrations of fumigants before incubation in the hatchery (Bluestar Poultry Egg Incubator). Before fumigation, each egg forming the specimen was swabbed on the more blunted shell area with sterile microbiological swab (FL MEDICAL S.r.l. Tollegla, Italy) soaked with $0.1 \%$ blank peptone water (Merck, Darmstadt-Germany). The tip of the swab with the cotton bud was broken into MacCartney bottle, each containing $5 \mathrm{ml}$ of $0.1 \%$ blank peptone water to form the neat. This was done to know the microbial load before the fumigant was applied.

Two different concentrations of fumigants were prepared. In the first preparation, three different volumes of $40 \%$ formalin (30,40 and 50) $\mathrm{ml}$ were added to $20 \mathrm{~g}$ of potassium permanganate crystals each in a different container. In the second preparation, equal volume of formalin $(40 \mathrm{ml})$ was added to different amounts of potassium permanganate crystals $(10,15$ and 25$) \mathrm{g}$ in different containers.

\section{Fumigation and incubation of egg}

Egg trays containing the egg samples were kept in separate air tight cardboard boxes of similar dimensions, $55 \mathrm{~cm} \times 42 \mathrm{~cm} \times 30 \mathrm{~cm}$ in length, breadth and height respectively. A metal container containing different concentration of the fumigant was put in each box and sealed immediately with cellotape. Samples were fumigated for $20 \mathrm{~min}$ in a fumigation chamber and aired for $10 \mathrm{~min}$ for all treatments with the exception of the control group.

Swabs were again taken after fumigation to form the second neat. The fumigated eggs were set for a 21 -day incubation period at $37.7^{\circ} \mathrm{C}$ and $86 \%$ relative humidity prior to candling on the $18^{\text {th }}$ day for egg fertility determination and $90 \%$ relative humidity after candling. Light penetration of a fertile egg revealed a distinct dark spot indicating embryonic development as well as blood vessels and air bubbles. However, infertile egg showed no distinct dark spots and egg content was clear, showing no signs of embryonic development. The specimen (bottles containing the neat), 
before and after fumigation, were delivered on ice to the Microbiology laboratory of CSIRAnimal Research Institute within four hours for laboratory investigation.

\section{Laboratory techniques}

\section{Specimen preparation}

One (1) $\mathrm{ml}$ of each neat was aseptically transferred into sterile screw cap MacCartney bottles each containing $9 \mathrm{ml}$ of $0.1 \%$ sterile blank peptone water [Merck, DarmstadtGermany]. This was incubated at $37^{\circ} \mathrm{C}$ for 10-15minutes in a bacteriological incubator [Wagtech] (Collins et al., 1995). Samples were serially diluted using 10 -fold serial dilution into five others sterile MacCartney bottles containing $0.1 \% 9 \mathrm{ml}$ peptone water. Different pipette tips were used for each dilution.

\section{Culturing and total viable count (aerobic plate count)}

Media preparations and bacterial culture procedures were carried out as described by Heritage et al. (1996). For total viable count technique, the pour-plate method was used. One (1) $\mathrm{ml}$ of each dilution was aseptically added to $9 \mathrm{ml}$ of molten Standard Plate Count Agar [Merck, Darmstadt-Germany] kept at 45$50^{\circ} \mathrm{C}$ in a water bath [Grant, OLS 200]. This was mixed by rotation and poured into $9 \mathrm{~cm}$ sterile Petri dish. It was allowed to cool, set and was incubated at $37^{\circ} \mathrm{C}$ for $24-48 \mathrm{hrs}$. After incubation, plates showing between 30-300 colonies were selected and counted (Collins et al., 1995) using electronic colony counter [Stuart Scientific]. Counts were derived by multiplying the colony(s) counted by the dilution factor. The counts obtained were expressed as $\mathrm{x}^{*} 10^{\mathrm{y}} \mathrm{cfu} / \mathrm{ml}$, where $\mathrm{x}$ is colony counted, $10^{\mathrm{y}}$ is the dilution factor and $\mathrm{cfu} / \mathrm{ml}$ as colony forming unit per millilitre.

\section{Total coliform count}

Using the plate-count technique, one (1) $\mathrm{ml}$ of each dilution was aseptically put into $9 \mathrm{~cm}$ Petri dish. Nine (9) $\mathrm{ml}$ of molten Membrane Lactose Glucuronide Agar (MLGA) [Oxoid, CM 1031 Hamsphire - England] kept at 45$50^{\circ} \mathrm{C}$ in a water bath (Collins et al., 1995) was added, mixed by swirling and allowed to set. Plates were incubated at $37^{\circ} \mathrm{C}$ for $24-$ $48 \mathrm{hrs}$ and examined for colonial morphology. Counts for each plate were multiplied by the dilution factor to obtain the number of colonies per sample.

\section{Faecal coliform count}

Using the plate-count technique, one (1) $\mathrm{ml}$ of each dilution was aseptically put into $9 \mathrm{~cm}$ Petri dish. Nine (9) ml of molten Membrane Lactose Glucuronide Agar (MLGA) [Oxoid, CM 1031 Hamsphire - England] kept at $45-50{ }^{\circ} \mathrm{C}$ in a water bath was added, mixed by swirling and allowed to set. Plates were incubated at $42^{\circ} \mathrm{C}$ for $24-48 \mathrm{hrs}$ and examined for colonial morphology. Colonies showing greenish colour indicating faecal coliforms were selected and counted.

\section{Subculturing, isolation and identification of bacteria}

Impure cultures on primary media were purified by subculturing onto selected secondary media to obtain discrete colonies. Using a sterile inoculating loop, the neat samples were platedout onto Blood Agar [Merck, DarmstadtGermany] and Xylose Lysine Desoxycholate (XLD) agar [Oxoid, CM 0469, Hamsphire England] (Heritage et al., 1996). Plates were incubated aerobically at $37^{\circ} \mathrm{C}$ for $24-48 \mathrm{hrs}$ in a bacteriological incubator (Wagtech). Cultures were examined for colonial characteristics on the media. 
After overnight incubation, colonial morphology of organisms was studied for size, shape, outline, colour and change in medium on various media. Standard microbiological techniques including Gram staining were used to determine cellular morphology of organisms using compound microscope magnified at x100 with oil immersion. Organisms were isolated and identified using biochemical tests: Motility Indole Urea (MIU) [Lioflichems.r.l. Bacteriology Products, 610236, Italy], Catalase, Triple Sugar Iron (TSI) [Oxoid, CM 0277, Hamsphire - England] and haemolysis. A well isolated colony was transferred onto the MIU agar with an inoculating needle for three test tubes. A loose cotton plug was placed over each test tube and incubated at $37^{\circ} \mathrm{C}$ for $18-24 \mathrm{hrs}$ to detect motility, urease enzyme activity and indole production ability of microbes. A small number of microbes was transferred using a sterile inoculating loop unto a microscopic slide devoid of any agar traces. A drop of 3\% hydrogen peroxide was put onto the microbes on the slide using a dropper. Detection of bubbles indicates microbial production of catalase. To detect the haemolytic ability of microbes, a strain of a single colony was inoculated on blood agar and incubated at $35^{\circ} \mathrm{C}-37^{\circ} \mathrm{C}$ for $24 \mathrm{hrs}$. Haemolytic activity was characterized by an absolutely or partially clear area around colonies. Nonhaemolytic microbes were differentiated by a dark brownish coloration around a colony. To detect the reaction of microbes with glucose, sucrose, lactose and iron, a strain of a single colony was inoculated and streaked on the TSI agar slant. A loose cotton plug was placed over the tube and incubated at $35^{\circ} \mathrm{C}$ in ambient air for 18-24hrs.

\section{Data analysis}

Data analysis was carried out with the Statistical Package for Social Sciences (SPSS) software (20.0). Following normality check of the data, Wilcoxon Signed-Rank test was used to compare median differences of bacteria load before and after fumigation. The Mann Whitney-U test was used to compare the mean ranks of bacteria load for the control and treatment groups. Chi-squared test was used to assess percentage hatchability of egg samples. Mean bacterial load before and after formaldehyde treatment and their standard errors were compared (Fig. 1).

\section{Results and discussion}

\section{Fertility and hatchability of eggs}

Out of the 210 Lohmann Brown eggs used in the study, $107(51 \%)$ were observed to be fertile, $58(54.2 \%)$ of which were successful in hatching. Pairwise comparisons using Chisquare test revealed that hatchability of the control group differed significantly from four formaldehyde-treated groups of eggs with formaldehyde concentration (FC) $30 / 20 \mathrm{ml} / \mathrm{g}$ showing the highest level of significance $\left[\chi^{2}\right.$ (1) $=14.71 ; P=0.0001$, Table 1]. 


\section{TABLE 1}

Formaldehyde treatment of G. g. domesticus eggs and their percentage hatchability.

\begin{tabular}{|c|c|c|c|c|c|}
\hline \multirow{2}{*}{$\begin{array}{l}\text { CFTG (ml/g) })^{\mathbf{1}} \\
\text { Control 00/00 }\end{array}$} & \multicolumn{2}{|c|}{$\operatorname{NIE}(\mathbf{F E})^{2}$} & \multirow{2}{*}{$\begin{array}{l}\text { NEH } \\
\frac{(\% \text { ha. })^{3}}{3(15.00)}\end{array}$} & \multirow[t]{2}{*}{$\mathrm{DP}(95 \% \mathrm{CI})^{4}$} & \multirow[t]{2}{*}{$\begin{array}{l}\chi^{2}(\mathrm{df}) \\
\text { P-value }\left(\mathrm{PC}^{*}\right)\end{array}$} \\
\hline & 10 & $(20)$ & & & \\
\hline $30 / 20$ & 12 & (18) & $14(77.78)$ & $62.78(31.61,79.21)$ & $14.71(1) ; 0.0001$ \\
\hline $40 / 20$ & 12 & (18) & $12(66.67)$ & $51.67(20.56,71.32)$ & $10.31(1) ; 0.0013$ \\
\hline $50 / 20$ & 12 & (18) & $11(61.11)$ & $46.11(15.31,67.10)$ & $8.43(1) ; 0.0037$ \\
\hline $40 / 10$ & 16 & (14) & $4(28.57)$ & $13.57(13.39,41.42)$ & $0.9(1) ; 0.3427$ \\
\hline $40 / 15$ & 17 & (13) & $7(53.85)$ & $38.85(6.40,63.79)$ & $5.46(1) ; 0.0195$ \\
\hline $40 / 25$ & 14 & (16) & $7(43.75)$ & $28.75(-0.73,53.80)$ & $3.56(1) ; 0.0592$ \\
\hline
\end{tabular}

*Pairwise comparisons (PC) of control and formaldehyde treatment $(\mathrm{ml} / \mathrm{g})$ groups.

$\chi^{2}$, Chi-square; CI, confidence interval. Hatchability of the control group differed significantly from four formaldehyde-treated groups of eggs.

Data are expressed as numbers, percentages $(95 \% \mathrm{CI})$.

${ }^{1}$ CFTG: Control and formaldehyde treatment $(\mathrm{ml} / \mathrm{g})$ groups.

${ }^{2}$ NIE (FE): Number of infertile eggs (fertile eggs).

${ }^{3} \mathrm{NEH}$ (\%ha.): Number of eggs hatched (percentage hatchability).

${ }^{4} \mathrm{DP}(95 \% \mathrm{CI})$ : Difference in percentages $(95 \% \mathrm{CI})$.

Although, formaldehyde disinfection of eggs is reported to improve upon hatchability (Shahein \& Sedeek, 2014) in line with the findings of this study, many other factors are important. Fertility and hatchability of poultry eggs are influenced by many factors including diet (Brillard, 2007; Javanka et al., 2010), egg factors such as weight, shell thickness and porosity, shape index and the consistency of the content (Narushin \& Romanov, 2002), hen age (Insko et al., 1947; Alsobayel, 1992) and optimum cock to hen ratio (King'Ori, 2011). Adequate diet in both quality and quantity is fundamental to production of good quality and number of eggs and semen (Brillard, 2007), which result in improved fertility and hatchability (Javanka et al., 2010). In particular, provision of fertile eggs with optimum environmental conditions including incubation temperature of $37.8^{\circ} \mathrm{C}$ (Lourens et al., 2007) or a range of $37.2^{\circ} \mathrm{C}$ and $37.7^{\circ} \mathrm{C}$, egg turning (Yoshizaki \& Saito, 2003; King'Ori, 2011) and relative humidity $(60-80 \%)$ are fundamental to stimulating embryonic development until hatching (French, 1997). Under similar management practice and conditions of incubation, all other factors except disinfection status could be said to be similar in both control and treated groups of eggs following randomization. The significantly high percentage of hatchability in formaldehyde-treated groups of eggs highlights the importance of egg disinfection in poultry production.

\section{Disinfection of eggs}

Comparison of mean bacterial loads on eggs before and after formaldehyde fumigation showed that FC $30 / 20 \mathrm{ml} / \mathrm{g}$ appears to have 
the best bacterial load reduction effect on the eggs (Fig. 1).

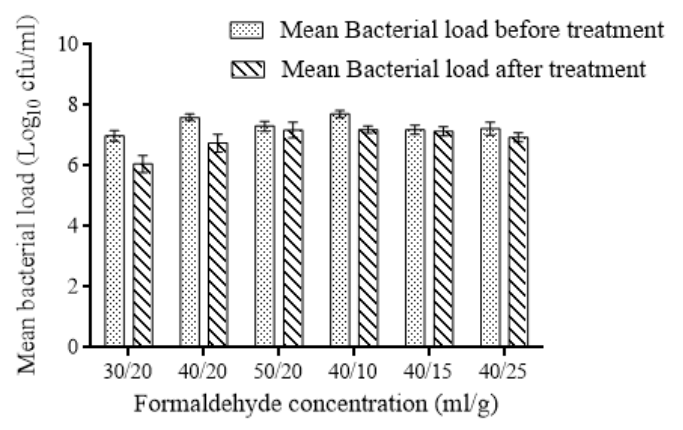

Fig. 1: Mean bacterial load before and after formaldehyde treatment of G. g. domesticus eggs.

Using Gram-staining and biochemical tests, five bacterial species: Escherichia coli, Enterobacter sp., Bacillus cereus, Staphylococcus aureus and Micrococcus sp. were identified with the two coliform bacteria, E. coli and Enterobacter sp., dominating. Comparison of median differences of bacterial load on eggs before and after formaldehyde treatment by Wilcoxon Signed-Rank Test showed marginal significance in bacterial load reduction following formaldehyde egg treatment $(Z=-2.016, p=0.044)$. This difference was observed for bacterial load between the control group and the treated group with FC $30 / 20 \mathrm{ml} / \mathrm{g}(U=3.0, p=0.047)$.

Microbial contamination of eggs including Escherichia coli, Bacillus cereus, Enterobacter sp. (Oviasogie et al., 2016), Staphylococcus aureus (McMullin, 2004), virulent E. coli (Chousalkar et al., 2010), Salmonella infantis (Chousalkar et al., 2013) present a lot of problems to commercial hatchery and its product, the chick. Within the first few minutes after lay, the eggshell is most ineffective barrier to bacterial invasion (Sparks, 1987). Under suitable conditions of moisture and temperature differential between the egg and the surrounding liquid (Lock et al., 1992; Graham et al., 2018), presence of shell microfractures (De Reu et al., 2005), faecal contamination (Oviasogie et al., 2016), among others, bacteria enter egg shell and its membranes. This could result in infection and killing of developing embryo, reduction in hatchability (Cadirci, 2009), spread of infection to hatched chicks through contact with contaminated eggshells and hatchery equipment (Cason et al., 1994) as well as food safety concerns when human pathogens are involved. The marginally significant bacterial load reduction following formaldehyde egg treatment with $30 / 20 \mathrm{ml} / \mathrm{g}$ in this study appeared to have had an important positive impact on hatchability (Table 1), highlighting the importance of egg disinfection in poultry production.

\section{Conclusion}

The results of the present study suggest that disinfection of Gallus gallus domesticus eggs with formaldehyde concentration (FC) 30/20 $\mathrm{ml} / \mathrm{g}$ results in highly significant improvement in hatchability. A FC of 30/20 ml/g produced the best domestic fowl egg disinfection compared to other FCs and hatchability decreased with increasing formalin volume. Therefore, the combination of egg disinfection with FC 30/20 ml/g and other relevant factors such as adequate diet in both quality and quantity, optimum cock to hen ratio, maintenance of optimum environmental hygiene and incubation conditions is expected to improve upon egg fertility and hatchability considerably.

\section{Acknowledgements}

Special appreciation goes to management of Council for Scientific and Industrial Research-Animal Research Institute (CSIRARI) for granting permission to use hatchery and laboratory facilities. The advice and 
technical assistance of Doreen Owusu-Ntumi, Gabriel Adu-Aboagye, Thomas Eghan and Leonardo Agbornegah (CSIR-ARI, Accra) are acknowledged.

\section{References}

Abdul, A. S. B., Sabry, A. H. \& Baling, A. E. (2012) Microbial Quality and Content Aflatoxins of Commercially Available Eggs in Taif, Saudi Arabia. Afric. J. Micro. Res. 6 (13), 3337 3342.

Alsobayel, A. A. (1992) Effect of protein rearing diet and age on fertility and hatchability parameters of Saudi Arabian Baladi chickens. J. King Saudi Univ. 44, 7 - 54.

Bailey, J. S., Cason, J. A. \& Cox, N. A. (1998) Effect of Salmonella in young chicks on competitive exclusion treatment. Poult. Sci. 77, $394-399$.

Berrang, M., Cox, N. \& Bailey, J. (1995) Measuring air-borne microbial contamination of broiler hatching cabinets. The J. of Appl. Poult. Res. 4, $83-87$.

BRILlard, J. P. (2007) Control of fertility in turkeys: the impact of environment, nutrition and artificial insemination technology. Poultry Industry Technical articles.Accessed Sept. 2018. https://www.cabdirect.org/cabdirect/FullTextPDF/2006/20063209158.pdf

CADIRCI, S. (2009) Disinfection of hatching eggs by formaldehyde fumigation-A review. Arch. Geflügelkd 73, $116-123$.

Cason, J. A., Cox N. A. \& Bailey, J. S. (1994) Transmission of Salmonella typhimurium during hatching of broiler chicks. Avian Dis. 38, 583 -588 .

Chousalkar, K. K., Flynn, P., Sutherland, M., Roberts, J. R. \& Cheetham, B. F. (2010) Recovery of Salmonella and Escherichia coli from commercial egg shells and effect of translucency on bacterial penetration in eggs. Int. J. Food Microbiol. 142 (1 - 2) 207 - 213.
Chousalkar, K. K., Roberts, J. R., Sexton, M., May, D. \& Kiermeier, A. (2013) Effects of egg shell quality and washing on Salmonella Infantis penetration. Int. J. Food Microbiol. 165 (2), $77-83$.

Collin, C. H., Lyne, P. M. \& Grange, J. M. (1995) Collins and Lyne's Microbiological Method: Antimicrobial Susceptibility Test, 7th ed., Oxford: Butterworth-Heinemann, pp. 178 205.

De Reu, K., Grijspeerdt, K., Heyndrickx, M., Zoons, J., De Baere, K., Uyttendaele, M., Debevere, J. \& Herman, L. (2005) Bacterial eggshell contamination in conventional cages, furnished cages and aviary housing systems for laying hens. Brit. Poult. Sci. 46, $149-155$.

Fasenko, G. M., Christopher, E. E. O. \& Mumullen, L. M. (2009) Spraying Hatching Eggs with Electrolyzed Oxidizing Water Reduces Eggshell Microbial Load Without Compromising Broiler Production Parameters. Poult. Sci. 88, 1121 - 1127.

French, N. A. (1997) Modelling incubation temperature: The effect of incubator design, embryonic development and egg size. Poult. Sci., 76, $124-133$.

Graham, L. E., Teague, K.D., Latorre, J. D., Yang, Y., BaXter, M. F. A., Mahaffey, B. D., HernandeZ-Velasco, X., Bielke, L. R., Hargis, B. M. \& Tellez, G. (2018) Use of probiotics as an alternative to formaldehyde fumigation in commercial broiler chicken hatch cabinets. J. Appl. Poult. Res. 27 (3), 371 - 379.

Hayretdag, S. \& Kolankaya, D. (2008) Investigation of the effects of pre-incubation formaldehyde fumigation on the tracheal epithelium of chicken embryos and chicks. Turk. J. Vet. Anim. Sci. 32, 263 - 267.

Heritage, J., Evans, E. G. \& Killington, R.a. (1996) Introductory Microbiology (Studies in Biology). Pages 129-138. 1st ed. Cambridge University Press, Cambridge. 
Insko, W. M. J. R., Steele, D.g. \& Whiteman, E. T. (1947). Reproductive phenomena in ageing hens. Kentucky Agr. Exp. Sta. Bull. 498, 1 23.

JASANOFF, S. S. (1987). Contested boundaries in policy relevant science. Soc. Stud. Sci. 17, $195-230$.

Javanka, L., Duuragic, O. \& Sredanovic, S. (2010) Use of feed from brewery by- products for breeding layers. Romanian Biotech. Lett. 15, $5559-5565$.

KaudLa, T. J. (1999) The effect of antibiotic, disinfectant and formaldehyde gas on hatchability of broiler eggs. J. Food Technol. Afr. 4, 55 -58 .

Kim, A., Lee, Y. J., Kang, M. S., KwaG, S. I. \& ChO, J. K. (2007) Dissemination and tracking of Salmonella spp. in integrated broiler operation. J. Vet. Sci. 8, $155-161$.

KIM, J. H. \& KIM, K. S. (2010) Hatchery hygiene evaluation by microbiological examination of hatchery samples. Poult. Sci. 89, $1389-1398$.

KING'ORI, A. M. (2011) Review of the factors that influence egg fertility and hatchability in poultry. IJPS 10 (6), $483-492$.

Lock, J. L., Dolman, J. \& Board, R. G. (1992) Observations on the mode of bacterial infection of hen's eggs. FEMS Microbiol. Letters 100, $71-74$.

Lourens, A., Van Den Brand, H., HeetKamp, M. J. W., Meijerhof, R. \& Kemp, B. (2007) Effects of eggshell temperature and oxygen concentration on embryo growth and metabolism during incubation. Poult. Sci. 86, $2194-$ 2199 .

Mcmullin, P. (2004) A Pocket Guide to Poultry Health and Disease. Poultry Site. Accessed Sept. 2018. http://www.thepoultrysite.com/ diseaseinfo/143/staphylococcosis-staphylococcal-arthritis-'bumble-foot/
Narushin, V. G. \& Romanov, M. N. (2002) Egg physical characteristics and hatchability. World's Poult. Sci. J. 58, 297 - 303.

Oviasogie, E. F., Ogboghodo, B. I., Beshiru, A., Omoregie, O. B., Ogofure, P. \& Ogofure, G. A. (2016) The microbial burden load of eggshells from different poultry rearing systems in Ekosodin Village, Edo State, Nigeria. JASEM 20 (2), 227 - 231.

Salthammer, T., Mentese, S. \& Marutzky, R. (2010) Formaldehyde in the indoor environment. Chem. Rev. 110, 2536 - 2572.

Scott, T.A. \& Swetnam, C. (1993) Screening sanitizing agents and methods of application for hatching eggs. I. Environmental and user friendliness. J. Appl. Poult. Res. 2, 1 - 6.

Shahein, E. H. A. \& Sedeek, E. K. (2014) Role of spraying hatching eggs with natural disinfectants on hatching characteristics and eggshell bacterial counts. Egypt. Poult. Sci. 34, $213-$ 230 .

Sparks, N. H. C. (1987) The hen's eggshell: A resistance network. Aslib Index Theses 36, 294.

Swenberg, J. A., Moeller, B. C., Lu, K., Rager, J. E., Fry, R. C. \& Starr, T. B. (2013) Formaldehyde carcinogenicity research 30 years and counting for mode of action, epidemiology, and cancer risk assessment. Toxicol. Pathol. 41, 181 - 189.

UNITED STATE DEPARTMENT OF HEALTH AND HUMAN SERVICES (USDHHS) (2010) Report on carcinogens background document for formaldehyde. US Department of Health and Human Services, Research Triangle Park, NC. Accessed Oct. 2018. https://ntp.niehs. nih.gov/ntp/roc/twelfth/2009/november/formaldehyde_bd_final.pdf

Whistler, P. E. \& Sheldon, B. W. (1989) Biocidal activity of ozone versus formaldehyde against poultry pathogens inoculated in a prototype setter. Poult. Sci. 68 (8), 1068 - 1073. 
Willinghan, E. M., Sander, J. E., Thayer, S. G. \& Wilson, J. L. (1996) Investigation of bacterial resistance to hatchery disinfectants. Avian Dis. 40 (3), 510 - 515.

Yildirim, I., Ozsan, M. \& Yetisir, R. (2003) The use of oregano (Origanum vulgare L) essential oil as alternative hatching egg disinfectant versus formaldehyde fumigation in quails (Coturnix coturnix japonica). Revue M'ed. V'et. 154, $367-370$.

Yoshizaki, N. \& SAito, H. (2003) Changes in shell membranes during the development of quail embryos. Poult. Sci., 81, 246 - 251.

Received 30 Jan 20; revised 06 Jan 21. 